\title{
Annick Payne \\ Determination in the Anatolian Hieroglyphic Script of the Empire and Transitional Period
}

\author{
https://doi.org/10.1515/aofo-2017-0019
}

\begin{abstract}
The Anatolian Hieroglyphic script is a mixed writing system which contains both phonetic and semantographic signs. The latter may be used in the function of logogram and/or determinative. A dedicated study of the script's determinatives has so far not been undertaken but promises insight into structures of mental organization and script development. Because of its pictorial character, individual signs can occasionally be shown to act in a dual capacity, as icons and signs of writing. This article forms part one of a diachronic study of the determinative system, and adresses the period $13^{\text {th }}-10^{\text {th }}$ century BC.
\end{abstract}

Keywords: Ancient Anatolian writing systems, Anatolian Hieroglyphic script, determinatives

\section{Introduction}

In the Anatolian Hieroglyphic script $(\mathrm{AH})$, determination is one function of the class of semantographic signs. Alternatively, semantographic signs may function as logograms. While logograms represent a word to be read out, determinatives are not intended to be read out, instead, they mark their host word as belonging to a specific semantic category. Thus, determinatives are mute graphemes that act as reading aids, and they are dependent on a host word; with very few exceptions, ${ }^{1}$ the determinative is placed in front of the host. Different relationships between determinative and host are possible: they may be coordinated or the host may be subordinate to a determinative representing a superordinate category under which several hosts may be subsumed. The script shows numerically equal relationships where one determinative is used for one host, with the aim of reinforcing - less frequently, obstructing - the reading, or of disambiguating it. There are cases where one determinative is used for a group of host words, and the reverse, where multiple determinatives, used alternatively, refer to a single host. Finally, it is possible to combine several, mainly two, rarely three determinative signs in a compound. ${ }^{2}$

The principle of using recognisable pictures as signs of writing requires that determinative signs depict concrete objects; at the same time, determinatives frequently refer to abstract notions, such as a category. The ancient scribes made use of several principles to depict the undepictable, such as referring to the intended with the help of semantic or phonetic links. ${ }^{3}$ To mention but one example, because of a semantic link, the depiction of a vessel used in an annual festival becomes the icon representing the concept 'year'. ${ }^{4}$ Even concrete objects were depicted in a stereotypical, standardized manner rather than aiming at a realistic copy of the real world referent. The iconic potential of hieroglyphic signs was deliberately explored and exploited, and the reader needs to be aware of a level of script-internal reference between signs.

1 Two frequent post-positioned determinatives are signs URBS and REGIO; cf. also below the discussion of the sign LITUUS. On the position of the sign * 404 , cf. Goldwasser/Payne (forthcoming).

2 Cf. in detail Payne (in press ${ }^{1}$ ) on the system of determination; Payne (in press ${ }^{2}$ ) on compound determinatives.

3 Cf. Payne (2015: 23-26) with lit.; Payne (in press ${ }^{1}$ ).

4 Cf. Marazzi (2010: 236).

Annick Payne, Universität Bern, Institut für Archäologische Wissenschaften, Abteilung Vorderasiatische Archäologie, Länggassstr. 10, CH-3012 Bern, Switzerland, E-Mail: annick.payne@iaw.unibe.ch 
The system of determination expanded greatly throughout the course of time. While we have no first hand accounts on scribal training in this script, the evidence of the surviving inscriptions suggests that the ancient scribe would have had an awareness of the historical development of the writing system, going back centuries. This can be gleaned from occasional anachronistic usage of signs in a manner that ordinarily belongs to much earlier stages of the script. ${ }^{5}$

\section{Diachronic Perspective}

The system of determination continued to develop over the centuries during which the AH script was in use. Different determinatives are used within any given period, and may in subsequent periods continue to be used, change or expand their usage, or disappear. Summarily, we note the following chronological pattern: during the Empire period, determination was not wide-spread. This is partly due to the surviving material evidence: on seals, beyond the distinction of male vs. female personal names, there is no great need to use determinatives as the information recorded is exceedingly limited and sufficiently distinct. The use of determinative signs is linked to the rise of inscriptions on stone and, presumably, to a lost corpus of handwritten texts. During the so-called 'dark ages', determination was still relatively infrequent, though increasing in the $10^{\text {th }}$ century BC. It is only at the end of the $10^{\text {th }} /$ beginning of the $9^{\text {th }}$ century $\mathrm{BC}$ that the situation changes: a significant increase in the number of determinatives introduces many determinatives which remain frequent in the following centuries. There is continued growth in the corpus of determinatives. From the $9^{\text {th }}$ to mid $8^{\text {th }}$ century BC, this growth is generally slower than the explosive growth at the end of the $10^{\text {th }} /$ beginning of the $9^{\text {th }}$ century BC; another peak is reached at the end of the $8^{\text {th }} /$ beginning of the $7^{\text {th }}$ century BC.

Table 1: Growth of Determinative Corpus

\begin{tabular}{ll}
\hline Centuries BC & Tendencies \\
\hline $13^{\text {th }}$ & - few determinatives \\
\hline $12^{\text {th }}$ & - proximity to Hittite cuneiform system \\
\hline $11^{\text {th }}$ & - small number of additional determinatives \\
\hline $10^{\text {th }}$ & - small number of additional determinatives \\
\hline Late $10^{\text {th }} /$ Early $9^{\text {th }}$ & - gradual increase in number of determinatives \\
\hline $9^{\text {th }}$ to $8^{\text {th }}$ & - great increase in number of determinatives \\
\hline Late $8^{\text {th }} /$ Early $7^{\text {th }}$ & - slower growth of corpus of determinatives \\
\hline
\end{tabular}

While there is a clear correlation between a larger amount of surviving texts from any given period and a larger amount of determinatives, as the following table shows, ${ }^{6}$ this does not serve to explain the growth of the system as the only, or even the dominant factor.

5 Examples, e.g. for the sign ${ }^{\star} 386\left(\mathrm{VIR}_{2}\right)$, are discussed in Payne (in press $\left.{ }^{2}\right)$.

6 Abbreviations used: $\mathrm{L}=$ late, $\mathrm{M}=\mathrm{mid}, \mathrm{E}=$ early. Numbers 7-13 refer to centuries $\mathrm{BC}$, higher numbers to words counted in the attested inscriptions for the respective periods.

The table is based on words counted as a correlative measure of text length from a representative corpus of AH inscriptions, specified in the following. If determinatives are attested across several but not subsequent periods in the same manner, they are considered existent for the entire time span from their earliest to latest attestation, rather than ad hoc new creations in subsequent periods. Unless major new text finds contribute different material, the correlations shown in the table can be considered representative. The following inscriptions form the basis for this table: the Corpus of Hieroglyphic Luwian Inscriptions Vol. 1 (Hawkins 2000) plus inscriptions AFYON, AIMEE GIRON, ALEPPO 4, ALEPPO 5, ALEPPO 6, ALEPPO 7, ÇİNEKÖY, EMIRGAZİ, GEMEREK, KARAKUYU, KIRŞEHIR, İSTANBUL 2, MALKAYA, POTOROO, SÜDBURG, TALL ŠṬīB, TELL AHMAR 6, YALBURT. 
Table 2: Distribution Pattern

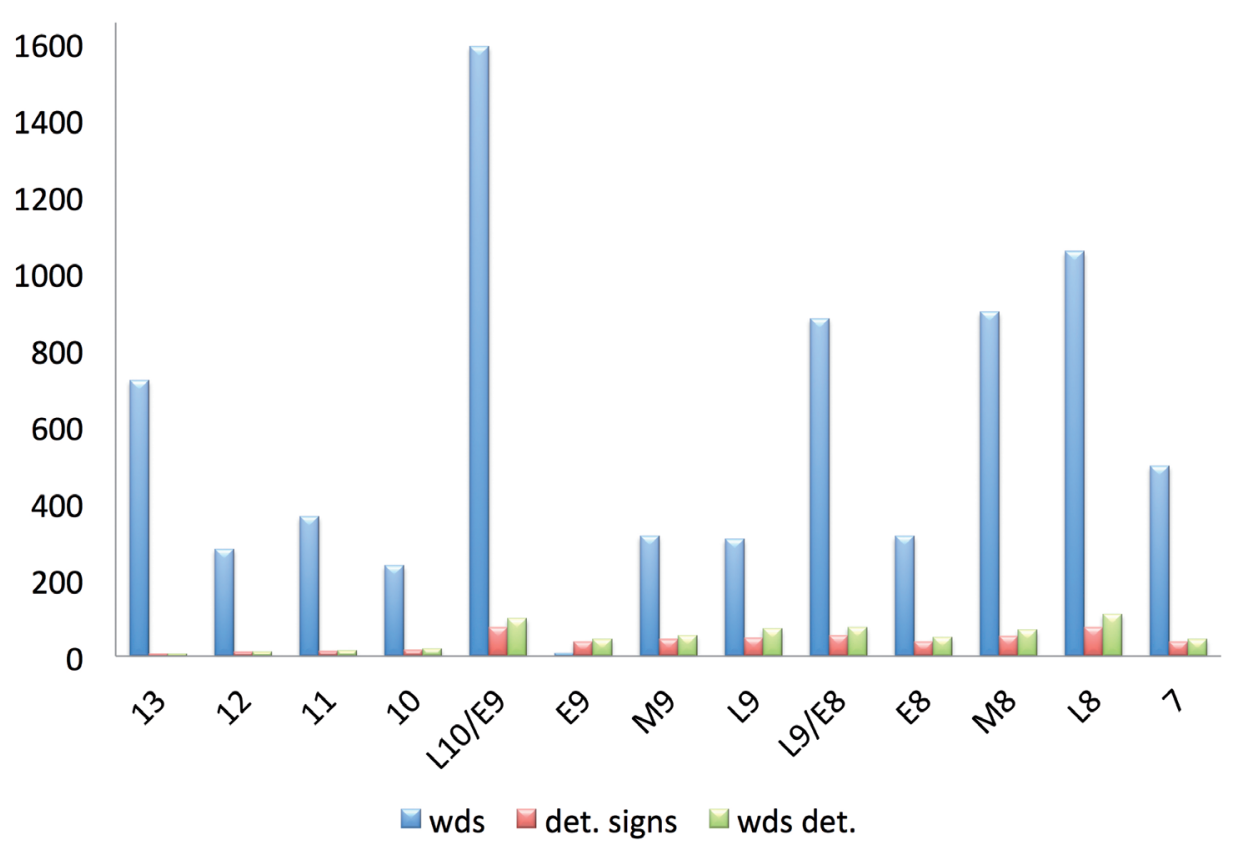

The above table correlates number of words attested with number of determinative signs used, and number of words determined in specific periods; later periods are subdivided according to conventional dating of the inscriptions, as the larger amount of text allows for finer differentiation. The relative disparity between number of determinative signs used and number of words determined is explained by the use of one determinative for a multitude of hosts. When comparing periods with one another, it is noteworthy that the larger number of texts from L9/E8 does not correspond to a rise in (new) determinatives similar to the changes occurring in L10/E9 and L8.

\section{Determination: The First Four Centuries}

\subsection{The $13^{\text {th }}$ Century BC}

Only a small text corpus survives from the Empire period ( $\left.13^{\text {th }} \mathrm{c} . \mathrm{BC}\right)$, and its several longer inscriptions do not show a significantly higher level of determination than their shorter contemporary counterparts. This supports a reconstruction of the history of AH determinative usage as suggested above (table 2). It may also be significant that determinatives used show a relative proximity to determinatives attested in Hittite cuneiform, i.e. there may have been a level of influence between the two writing systems used by the imperial administration. Such influence may be at the root of two post-positioned AH determinatives, URBS and REGIO. ${ }^{7}$ Why AH determinatives generally favour a position before their host is unknown, although one might speculate that a visual priming effect by the icon may have played a role, with the added benefit of at the same time marking the beginning of a word.

7 As the two hieroglyphic signs show a clear iconic relationship, one might speculate that the postposition of REGIO influenced the same position of URBS, as this is not shared by the cuneiform equivalent. 
Table 3: Empire/Early Determinatives

\begin{tabular}{|c|c|c|c|}
\hline \multicolumn{4}{|l|}{ DETERMINATIVE } \\
\hline Category & & АН & cun. \\
\hline Country & REGIO & E三 & к। \\
\hline City & URBS & $\Leftrightarrow$ & $\begin{array}{ll}\text { URU } \\
\end{array}$ \\
\hline Mountain & MONS & qnp & HUR.SAG \\
\hline Divinity & DEUS & (dp) & d \\
\hline Male person & $\mathrm{VIR}_{2}$ & OS & ${ }^{\mathrm{Lu}}{ }_{2}$ \\
\hline Human Being ${ }^{8}$ & 1 & 0 & 1 \\
\hline Strength & *273 & $\{\xi$ & - \\
\hline 'to kneel' & *85 & $\underset{23}{23}$ & - \\
\hline
\end{tabular}

With the exception of the signs ${ }^{\star} 273$ and ${ }^{*} 85$ (both introduced in the same inscription, YALBURT), all other Empire determinatives have a cuneiform counterpart, ${ }^{9}$ and they also form a single taxonomic group ('names'), which can hardly be accidental. ${ }^{10}$ Because of the ubiquitous nature of the group, all of the name determinatives were continued throughout the entire time that the script was in use, their purpose the disambiguation of different types of names.

It is worth emphasizing that the inscription YALBURT marks the departure point from a system of determination that appears if nothing else structurally very similar to cuneiform usage. ${ }^{11}$ The Yalburt inscription introduces three new determinative signs, ${ }^{\star} 273$, ${ }^{\star} 85$ and $\mathrm{VIR}_{2}$. The sign ${ }^{\star} 273$ appears as a verbal determinative of muwa-, ${ }^{12}$ 'to conquer', thereby establishing the semantic field of what would later become a generalized determinative. Subsequently, it is additionally used to determine iasaza-, 'dedicate(?)' (12 ${ }^{\text {th }}$ c. BC), warp(i)-, 'weapon; tool' $\left(10^{\text {th }}-\right.$ early $8^{\text {th }}$ c. BC), ${ }^{13}$ huttalli-, 'to smite' (late $9^{\text {th }}-$ early $8^{\text {th }}$ c. BC) and tub(a)i-, 'to strike' $\left(8^{\text {th }} \mathrm{c}\right.$. BC). With the exception of the hapax legomenon iasaza-, the sign ${ }^{*} 273$ thus determines a closely linked semantic group consisting of terms relating to strength and conquest. While the exact connotation of the sign ${ }^{\star} 273$ remains speculative, it could easily depict a weapon, i.e. a tool involved in the activity "to

8 Whether the personal marker is considered as first attested during the Empire or shortly after $1200 \mathrm{BC}$ depends on the dating of one single inscription, KIZILDAĞ 1. I support the Empire dating of d'Alfonso (2014: 230) contra Hawkins (2000: 434-435); or most recently Oreshko (2017).

9 The fact that cuneiform has quite a few determinatives that never appear in AH is largely a question of genre: there is no mention in the surviving AH corpus, for instance, of textiles, reptiles or green plants, and thus no need for determinatives corresponding to cuneiform TUG 2 , MUŠ or SAR.

10 On this group, cf. Payne (in press ${ }^{1}$ ).

11 In as much as the introduction of several new determinative signs in the YALBURT inscription may be considered a dating criteria, this could be seen as another point in favour of the currently discussed earlier date for the SÜDBURG inscription. On the dating of which cf. Klinger (2015); Oreshko (forthcoming, Dissertation FU Berlin 2012); Payne (2015: 78-84); note further that Goedegebuure (2011) suggests two possible links of content to the period of Suppiluliuma I.

12 Note the alternation of writings with $(16 \S 2 a)$ and without determinative $(11 \S 2)$ in this inscription.

13 On warp(i)-, cf. Yakubovich (forthcoming) who independently reaches a similar interpretation of what the sign *273 might depict. 
conquer', and thus likewise refer to its host on an iconographic level. As the logographic writing of muwa-, FORTIS, is attested in the same inscription, it is clear that the determinative was not derived from the logographic writing. Nor can one easily detect an iconographic relationship between the two signs.

The sign ${ }^{\star} 85$ depicts a kneeling leg, and is used to determine kwanza-, 'to kneel'. ${ }^{14}$ The match between host and icon would suggest that ${ }^{*} 85$ could also be used as a logogram for kneeling, although this is not attested. This reinforcement of host with a determinative expressing the identical notion forms the basic pattern which many later determinative signs will adhere to.

Of special interest because of its later development is the sign $\mathrm{VIR}_{2}$, originally used logographically in opposition to the sign FEMINA, to indicate male vs. female names on seals, and in compound logograms such as INFANS. It thus antedates the alternative and visually less salient personal marker ${ }^{\mathrm{I}} \mathrm{I}$ ). It is unclear whether this latter sign should be considered an abbreviated form of VIR , or whether it may have been formed after the cuneiform model, using a single vertical stroke instead of a wedge. VIR 2 soon begins to extend its determinative field beyond just personal names, and in the YALBURT inscription marks other words for person, including aliwan(ni)-, 'enemy', ${ }^{15}$ and the compound tadinzi huhanzi, 'fathers (and) grandfathers'. ${ }^{16}$ The development of the sign from a marker for persons to a generalized marker for the beginning of a word is described by Hawkins (2011: 51): "The stages of this development, best followed in the tenth to ninth century inscriptions of KARKAMIŠ and TELL AHMAR, seems to be approximately as follows: determinative of words denoting persons $>$ collectives (city, army) $>$ logograms rendering personal actions, especially those written with parts of the body (giving etc.) > logograms generally > phonetically written words with personal content ('my', 'name' etc.) > pronouns ('this', relative)." But note that the sign's original logographic function was still actively used in later periods, too. ${ }^{17}$

\subsection{The $12^{\text {th }}$ Century BC}

The transitional Period (12th to mid-10 $0^{\text {th }}$ centuries BC) introduces several new determinatives. Also, the use of $\mathrm{VIR}_{2}$ as a determinative for persons was extended in this period to include the words CAPUT- $t$ (ti)-, '(noble) man' and URBS+MI-n(i)-, 'camp(?)' (KARAHÖYÜK §§ 9; 13; 22); the latter can be semantically connected to the personal sphere as a place filled with people.

Exceptionally, the $12^{\text {th }}$ century BC includes one further post-positioned determinative, namely LITUUS in the writing wammi(LITUUS)-, 'to find'. The writing is first attested in a $12^{\text {th }}$ century BC inscription from KARAHÖYÜK (§ 3). While the edition in CHLI (Hawkins 2000: 289, 292) transliterates the passage as wa/i-miOCULUS(+?), I propose to re-analyse it as a variant of LITUUS with a slightly shorter, centrally positioned 'neck', ${ }^{18}$ on the basis that it bears only limited resemblance to the attested variants of OCULUS, ${ }^{19}$ a sign which is not otherwise used as a determinative before the $8^{\text {th }}$ century BC. The KARAHÖYÜK attestation would then form a pattern with later writings, as shown in the following table:

\footnotetext{
14 YALBURT block $6 \S 1$. On the basis of the iconic match discussed above, I consider the translation 'kneel' proposed by Hawkins (1995: 76) convincing; similarly but as a noun, cf. Poetto (1993: 42-43); contra Oreshko (forthcoming).

15 Contra Oreshko (forthcoming), who interprets the term as 'ruler', and previous interpretations as a royal title (Hawkins 1995: 26-28; Poetto 1993: 28-29 and n. 43), I follow the reading 'enemy', proposed by Yakubovich (2008).

16 On the curious spelling TÁ.AVUS cf. Hawkins (1995: 74).

17 Cf. Payne (in press ${ }^{2}$ ).

18 Melchert (pers. comm.) further points out the resemblance to the form attested in KARATEPE Hu. § 28.

19 Two variants are recorded: an almond-shaped eye with an eyebrow (AKSARAY; KARATEPE 1 Ho. § 49), and a very small, even circle (KARATEPE 1 Ho. $\S 58$ ). The sign on KARAHÖYÜK bears no resemblance to the AKSARAY variant of OCULUS, and differs from the sign attested in the KARATEPE inscription, in that it is considerably bigger and ends in an unexplained 'neck'.
} 
Table 4: wammi(LITUUS)-

\begin{tabular}{|c|c|c|c|}
\hline (A) & KARAHÖYÜK § 3 & wa/i-mi(LITUUS) & \\
\hline (B) & MARAŞ 8 § 3 & $w a / i-m i($ LITUUS)-ha & $\begin{array}{l}010 \\
1111 \\
P_{1}^{0} \\
0\end{array}$ \\
\hline (C) & KARKAMIŠ A15b § 23 & $w a / i-m i($ LITUUS)-ha & $\begin{array}{l}\text { व]0 } \\
\text { (1) } 910\end{array}$ \\
\hline (D) & KARABURUN § 6 & $w a / i-m i($ LITUUS)-ta & $\begin{array}{c}.1 \cdot \\
11 \\
0\end{array}$ \\
\hline (E) & ASSUR letters $\mathrm{f}+\mathrm{g} \S 42$ & |wa/i-mi(LITUUS)-si & 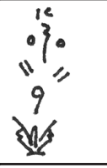 \\
\hline (F) & TELL TAYINAT 2 I. 3 §ii & $w a / i-m i($ LITUUS)-ha & $\frac{\text { ond }}{\text { IV(D) }}$ \\
\hline
\end{tabular}

Not only is the position of the determinative sign after the phonetic writing of the verbal stem unusual, even more noteworthy is that all attestations which include a verbal ending (B-F) seem to add this after the determinative, either below the LITUUS sign, or next to but following it in the normal reading order. The fact that this particular writing should stay so stable over several centuries must be significant. Melchert (pers. comm.) suggests that the sign may have had a rare phonetic value / ia/. Such a value could have been derived acrophonically from iyarri-, 'to extend', following Melchert's analysis (2010: 2) of the icon as, originally, a beam/shaft of light extending from the eye; secondarily, the sign was reanalyzed as a staff (LITUUS) which functioned as a symbol of power (loc.cit.: 3). If the proposed phonetic value were accepted, this would solve the structural problem of this writing, leading to a very regular writing of the verbal stem as $w a / i-m i-i a_{\mathrm{x}}-$.

Table 5: New Determinative Signs of the $12^{\text {th }}$ c. BC

\begin{tabular}{|c|c|c|c|}
\hline & Determinative & Category & Sign \\
\hline (A) & LITUUS & verbs of perception & \\
\hline (B) & INFANS & male descendant(s) & \\
\hline (C) & BONUS $_{2}$ & terms of 'goodness' & \\
\hline (D) & SOLIUM(+MI) & 'seat' and derivatives & \\
\hline
\end{tabular}


Table 5: (continued)

\begin{tabular}{llll}
\hline & Determinative & Category & Sign \\
\hline (E) & $* 273$ & $\begin{array}{l}\text { 1. terms of strength } \\
\text { 2. 'to dedicate' }\end{array}$ & \\
\hline (F) & $* 428$ & city name & \\
\hline (G) & MANUS & $? ?$ \\
\hline (H) & $* 256$ & $? ?$ \\
\hline
\end{tabular}

At least half of the newly introduced determinatives of this period were created via the practice of graphic reinforcement of the host, using the semantogram which repeats the phonetic reading of the host as a determinative (min. A-D); secondarily extended to other terms linked either linguistically (D) or semantically (E [with one exception to the group, cf. above]).

The $12^{\text {th }}$ century BC sees the introduction of several determinative signs that will subsequently grow into markers for specific categories. One example is the sign for 'male child', INFANS (an iconic compound of the icon for man (VIR $)$ and the giving hand), as the reinforcing determinative for nimuwizza-, 'son'. As of the late $9^{\text {th }}$ century BC, the sign was generalized as a determinative of relationship terms for male descendants further down the line, i.e. 'grandson', etc. Another example is BONUS $_{2}$ as determinative for wass(a)-, 'goodness', likewise marking a category of semantically related terms, namely pertaining to 'goodness'. This determinative, in contrast to INFANS, also undergoes a change on the iconic level, when the sign BONUS $_{2}-$ which has its origins on early Empire seals - is replaced with the variant BONUS; the two signs are closely linked semantically, yet their visual shape is not. While we do not know the motivation behind this, it is conceivable that a new symbol may have been created to express the same concept more forcefully also on the iconic level. Another frequent determinative first attested in the $12^{\text {th }}$ century BC but continuing until the end of AH script usage consists of the semantogram SOLIUM, occasionally enlarged by an additional element (transcribed $+M I) .{ }^{20}$ This determinative is used for related word stems, isnu(wa)-, 'to set, settle', as a-, 'seat' and as a-, 'to sit'.

In the $12^{\text {th }}$ century BC, the sign ${ }^{*} 273$ is used in an unexplained fashion for a hapax legomenon which cannot be linked to the otherwise coherent semantic group determined with this sign both before (cf. above)

20 The transcription $+M I$ is traditional and adopted by the edition in CHLI, yet note the observations by Hawkins/Morpurgo Davies (1978: 110) that in the case of SOLIUM, a phonetic indicator $+M I$ cannot be reconstructed, as the words determined, $a s a$ and isnu(wa)-, do not represent any sound(s) that this syllabic sign could refer to. Their interpretation as a graphic appendage, in analogy to the protusions on the Empire form of $i\left({ }^{\star} 209\right)$ is still a valid solution. However, this appendage may have had a meaningful iconic origin, i.e. depicting the arms of a chair (suggested by Melchert, pers. comm.); while it is possible that the original meaning was subsequently lost and the 'arms' generalized in accordance with the phonetic indicator, one should also consider that such generalization may be the invention of the modern scholar.

The usage of graphic variants with and without 'arms' are suggestive but not consistent enough to speak of a clear pattern, in particular the alternation in KARAHÖYÜK between the two forms defies explanation: 1 . the verb isnu(wa)- is commonly written without 'arms', with three exceptions (twice in determinative, once in logographic function); 2. the verb asa- is almost always written with 'arms' in logographic function (one exception: KARAHÖYÜK), always without in determinative function; 3. the noun $a s a$ - is always written without 'arms' in logographic function (only attested at Hama: HAMA 4; HAMA 5), in determinative function, two writings alternate: a compound MENSA.SOLIUM (KARKAMIŠ A6) vs. the SOLIUM with 'arms' (KARAHÖYÜK). Given the small number of occurrences, it is impossible to judge whether this pattern reflects regional or chronological differences, or should be considered graphic variation in the depiction of chairs with/without arms (artistic licence or material differences of a real life referent?). 
and after this period. Likewise unexplained is the determinative * 428 for the city named Taita. It is plausible that the sign depicts something which could have stood as the symbol for the city, yet the means by which the two are linked remains obscure as long as the sign remains uninterpreted. Melchert's analysis (1988: 39) of the sign in the verb taya- 'to steal' as a compound formed by the depiction of a storeroom with the sign for loss (MINUS) is attractive but it does not solve the question whether the use of the sign as a determinative of TaitaCity is linked merely by similarity of sound, or whether it marks the city as a den of thieves.

The use of MANUS as a determinative of $l i-{ }^{\star} 375-$, [verb of destruction], stands at the beginning of a wider practice that will become generalized, the determination of manual activities with the respective hand signs. The final determinative which may have arisen as early as the $12^{\text {th }}$ century BC (the only inscription in which it is attested can only roughly be dated to the transitional period ${ }^{21}$ ) is the sign ${ }^{\star} 256$ which determines $k a-{ }^{\star} 282$ $n a,{ }^{22}$ 'granary' (KARKAMIŠ A30h $\S 1$ ). The determinative uses a symbol for the granary, depicting pars pro toto either the floor of a grain pit, ${ }^{23}$ or cover of a grain silo. ${ }^{24}$ The sign ${ }^{\star} 255\left({ }^{\star} 256\right)$ is used to determine a group of nouns belonging to the semantic field of grain (harvest/storage/measurement): kaluna-, 'granary'; via a semantic link the noun mariyan(i)-, 'belonging to the field; harvest'; ${ }^{25}$ and zipattan(i)-, a measurement used, inter alia, for corn. With no obvious semantic or linguistic link to this group is the singular use of this sign as a determinative for tasa-, 'stele’ (KULULU $2 \S 2$ ).

\subsection{The $11^{\text {th }}$ Century BC}

Two $11^{\text {th }}$ century BC inscriptions (ALEPPO 6; ALEPPO 7) greatly expand the transitional usage of VIR 2 as a determinative of persons, to include a range of very specific persons: hastall(i)-, 'hero'; palistinizza-, 'Palestinean'; nimuwizza-, 'son'; tuppala-, 'scribe'; zid(i)- 'man' and the unknown noun zamarn(i)-. This usage stays true to the semantic category established, but diversifies it on the specific level.

The foot sign first appears as a determinative in this century, used for two similar sounding verbs, usa-, 'to lead (here)', ${ }^{26}$ and uppa-, 'to bring, ${ }^{27}$ Attestations of usa-, mainly with but occasionally without the determinative, date from the $11^{\text {th }}$ (ALEPPO $7 \S 7$ ) to the early $7^{\text {th }}$ century BC. The first appearance of (PES) uppa- may date a little later: it is first attested in the inscription IZGIN 2, the date of which is uncertain within the range $11^{\text {th }}$ $10^{\text {th }}$ century BC. In subsequent periods, the foot (in the two variants PES and $\mathrm{PES}_{2}$ ) is generalized as a determinative for verbs of motion, indicating as demonstrated by Yakubovich (2016) either centripetal ('hither') or centrifugal ('thither') motion. The writing system indicates the motional direction on an iconographic level: depending on whether the foot is placed in the direction of writing (PES, signifies centripetal motion), or against it $\left(\mathrm{PES}_{2}\right.$, signifies centrifugal motion); this is comparable to motion prefixes in the language and shows that the concept of 'hither and thither' found its expression in both lexicon and script.

21 Hawkins (2000: 177).

22 The reading of ${ }^{\star} 282$ remains obscure, nevertheless, the identification with ( $\left.{ }^{2} 255\right)$ kaluna-, 'granary’ seems to be assured (cf. Hawkins 1981: 161; 2000: 178). Cf. the following parallel passages: TELL AHMAR 5 §§ 2, 5, 16: (^256)ka-la/i/u-na-zi; MARAŞ 8 § 7 : |

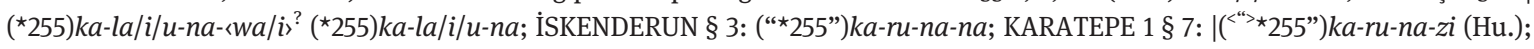
( $\left.{ }^{\star} 255\right) k a-r u-n a-z i$ (Ho.); HAMA 8 \& 2: (“`255”)ka-la/i/u-na-na.

23 Van den Hout (2010: 237-238).

24 Payne (2015: 108).

25 Cf. van den Hout (2010: esp. 239).

26 Cf. Yakubovich (2016: 85-87).

27 On Luwian uppa- vs. uba-, cf. Simon (forthcoming); Melchert (forthcoming); id. (2004); Starke (1990: 520 n. 1921); Yakubovich (2005: 244-248). 
Table 6: New Determinative Signs of the $11^{\text {th }}$ c. BC

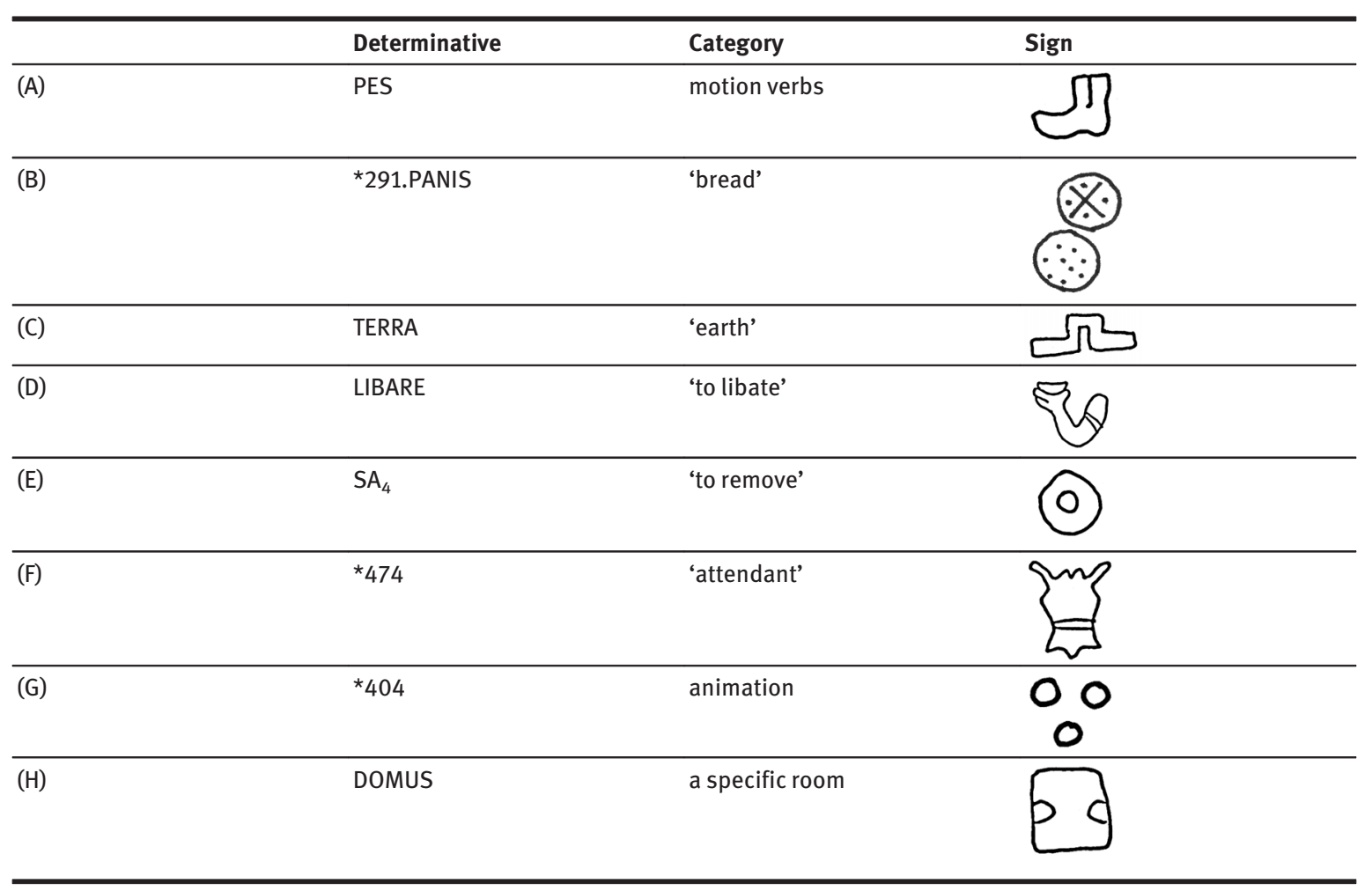

While the number of new determinatives created in this century is relatively small, it includes the first compound determinative, *291.PANIS, for turp(i)-, 'bread'. This compound consists of two iconically very similar signs, a fact that is lost in transliteration. As I have argued elsewhere, both signs depict loafs of bread, the main difference being a cross pattern on the uppermost loaf which probably represents incisions made by the baker to prevent an uncontrolled breaking of the crust during baking. ${ }^{28}$ Accordingly, the sign ${ }^{\star} 291$ should be considered an alternative bread sign, PANIS $_{2}$. The double determinative is used to express the notion of sufficiency via plurality, which would be appropriate in the context of the sentence it appears in: $a$-wa/i (PANIS $_{2}$.PANIS)tu+ra/i-pi-sa (LIBARE) $s a_{3}+r a / i<-l a$ ? $>$ - $h i$-sa $\|$ CAPERE.PANIS-sa-ha, '(there shall be) bread, libation and ...' (ALEPPO $6 \S 12$ ). Like the following two determinatives, this compound one repeats the information given by the host, supporting the reading with an easily understandable icon. ${ }^{29}$

Both the writing of (TERRA)taskwar(i)-, 'land; earth' and (LIBARE)sarlahid-, 'libation' operate in the same manner, by reinforcing the host with the same semantogram that could be used to write the word logographically. LIBARE continues in subsequent centuries as the determinative of linguistically related $\operatorname{sarl}(a) i-$, 'to libate', sarlatt(a)-, 'offering' and sasarla-, 'to offer'. TERRA continues as a determinative of taskwar(i)-, until the final days of the script, with two semantically linked new hosts joining the group, tagamm(i)-, 'land' and walilid(a)-, 'territory'. ${ }^{30}$

Another highly productive determinative introduced in the $11^{\text {th }}$ century $\mathrm{BC}$ is the sign $\left(\mathrm{SA}_{4}\right)$, a depiction of a seal, to determine $\operatorname{sann}(a) i-$, 'to remove'. In this instance, there is no obvious semantic or iconic relationship between determinative and host. Rather, the relationship is one of sound, meaning that the determinative acts on a different level and primes the phonetic reading through prepositioning of the first syllable. At first glance, such a writing seems counterintuitive and unnecessarily complicated, as the prepositioned first syllable

28 Payne (in press²).

29 In the late $10^{\text {th }}$ century BC, turp(i)- is determined with single PANIS (ARSUZ $1 \S 23$ ) or, in the parallel inscription, with the compound "402.PANIS (ARSUZ $2 \S 23$ ).

30 (TERRA)latra- will be discussed with the later period L10/E9. 
initially obscures the correct reading. It only works when the reader knows that the first sign is not to be read aloud, that it has to stay mute. In fact, this may be a rare instance of a ludic writing: a purely phonetic approach would lead to the wrong reading of $\mathrm{sa}_{4}$-sa-ni-, which in turn invokes the obstructive initial sign $\mathrm{SA}_{4}$, providing a phonetic rendering of the depicted 'seal' word, sas(a)-. Yet the seal, both as an icon and as an (at least initially) possible phonetic reading is a very deliberate false trail.

The determinative *474 for wassinass(i)-, 'attendant', was presumably introduced early, even though the first attestation is somewhat broken, and can only roughly be dated to the $11^{\text {th }}$ or $10^{\text {th }}$ century BC (IZGIN $1 \S 17$ ); it does not, unfortunately, preserve the determinative which is restored from parallel passages (MARAŞ $4 \S 14$; MARAŞ $14 \S 1$; KARKAMIŠ A24a2+3§ 1; A6 § 30). Of particular interest is a later usage which uses the same determinative in front of an Akkadian loanword, sariyas(i)- < ša rēši, 'attendant; eunuch' (ANCOZ 4 § 1); this emphasizes the strength of the semantic bond between determinative and host, which in this rare case overcomes linguistic borders. It is possible, though far from assured, that the sign $\star 474$ depicts clothing worn by attendants.

The sign of three small balls, * 404 , has been traditionally understood as the sign for animal, therefore transcribed ANIMAL, depicting pars pro toto the breath of living beings. The sign is highly complex and will be discussed in detail in a forthcoming article. ${ }^{31}$ The attestations ALEPPO $6(\S \S 6 ; 10)$ are the earliest occurrences of this sign, ${ }^{32}$ which is unusual in that it occurs only in determinative function, and moreover, can occur both before and after its host. As shall be argued, the fact that it is most commonly postpositioned attests to an iconic logic, namely to the depiction of breath being exhaled from the mouth of animal signs.

The exact meaning of the host sasad(i)-, ${ }^{33}$ determined with the sign DOMUS, remains unknown through lack of context in its single attestation but it seems clear that the relationship between determinative and host is that of superordinate to subordinate entity, i.e. house to specific room.

\subsection{Early to Mid-10 th Century BC}

The following section considers the development of most of the $10^{\text {th }}$ century BC but excludes the close of the century which marks the beginning of a new period with very significant new developments; the period from the $10^{\text {th }} / 9^{\text {th }}$ century to the disappearance of the AH script will be considered in further articles. The $10^{\text {th }}$ century $\mathrm{BC}$ is the period during which the above mentioned sign ${ }^{*} 386\left(\mathrm{VIR}_{2}\right)$ was generalized as a marker for the beginning of words. Also, the semantic field of INFANS was extended to include further relationship terms descending down the male line, such as nawa-, 'great-great-grandson' and nawanawa-, 'great-great-greatgrandson' (SHEIZAR §§ 4; 5).

The $10^{\text {th }}$ century $\mathrm{BC}$ saw the introduction of a similar number of new determinatives as the preceding century. Many of these originate from Karkamiš, which boasts a strong tradition of very ornamental hieroglyphic inscriptions in this period. Additionally, many previously introduced determinatives continued, or extended their usage. The extension of LIBARE to other related words has been already mentioned above (2.3.), as has the use of ${ }^{2} 255$ for kaluna-, 'granary' which has close but not altogether clear links to the writing $\left({ }^{\star} 256\right) k a-{ }^{\star} 282-n a$ (cf. above, 2.2). Likewise, the use of ${ }^{\star} 273$ for warp(i)-, 'weapon, tool', falls into the category of extending the usage to a field already introduced, namely terms relating to strength/conquest (cf. above, 2.1.). Similarly, the determination of terms relating to goodness is not new. But while previously the sign BONUS $_{2}$ was used, a sign already attested early on as an auspicious symbol on seals, as of the $10^{\text {th }}$ century BC, its role was taken over by a new sign, BONUS (as determinative of waliya-, 'to favour'; later of further terms of goodness). In contrast to the simple triangle $\mathrm{BONUS}_{2}$, the new sign of writing is considerably bigger and more elaborate. The replacement with a new sign seems to have been motivated by a desire to increase the iconicity, the replacement sign at least partly reflecting the change in material support, as the larger new sign would

31 Goldwasser/Payne (forthcoming).

32 Followed by ARSUZ $1 \& 2 \S 5$.

33 Hawkins (2011: 49) discusses two proposals, ‘bedchamber' or 'seal house, treasury’. 
have benefitted from the less confined writing surface on stone monuments and rock facades, as opposed to seals.

Table 7: New Determinative Signs of the $10^{\text {th }}$ c. BC (1)

\begin{tabular}{|c|c|c|c|}
\hline & Determinative & Category & Sign \\
\hline (A) & BONUS & terms relating to goodness & 89 \\
\hline (B) & PONERE & 'to place' & \\
\hline (C) & STELE & ‘stele’ & \\
\hline (D) & IUSTITIA & 'justice; rule' & 58 \\
\hline (E) & LONGUS & 'to extend' & \\
\hline (F) & MAGNUS.DOMINA & 'queen' & \\
\hline
\end{tabular}

The determinative PONERE, the placing hand, simply repeats the information contained in its host, $t u(w a)$-, 'to put, place'; this usage continues in subsequent centuries. The same pattern is shown by STELE for wanid-, 'stele', and by IUSTITIA as determinative and logogram of tarrawann(i)-, 'justice' (SHEIZAR § 2; ${ }^{34}$ ARSUZ $1 \S 2$ ). The STELE sign is an iconic compound of the symbol for a carved stone, LAPIS, and the tool used to create it, SCALPRUM. Another iconic compound is provided by the determinative LONGUS for $i(y a) r r i-$ 'to extend' (ARSUZ 1\&2 § 22). The determinative is a compound of two signs, MANUS+MINUS. The single vertical stroke MINUS also occurs in other compound signs, signalling a lack (cf. above, 2.2., sign *428). I would argue that in the sign LONGUS, it signals the lack of the usual denotation of the sign MANUS, leading the focus to its depiction as a stretched out hand, thus opening up a new field of meaning 'stretched out = long'. Thus, the second component of the sign interacts with the icon as a sign of writing, rather than as a real life referent.

A different kind of compound is at the base of MAGNUS.DOMINA, determinative of hassusar(i)-, 'queen'. The sign is formed in analogy to another compound sign, MAGNUS.REX, both combining the crowning volute meaning 'great' with the symbol for the highest (male/female) office. But the iconic depiction of king and queen are derived by different principles, the king being depicted pars pro toto with his pointed royal hat, while the queen is shown as a face in profile, also wearing her royal headgear. The genesis of this sign thus depends on context provided by the writing system rather than a straight forward depiction of a real life referent: as the sign for queen needed to be differentiated from the sign for king, the royal headgear was extended to show face and hair, thereby clearly marking the figure as female. The unmarked, male version of the sign was either created first, which seems likely, and/or considered the more central for the category 'royalty'.

34 For the redating of MEHARDE-SHEIZAR to the early $10^{\text {th }}$ century BC, cf. Dinçol et al. (2015: 63). 
Table 8: New Determinative Signs of the $10^{\text {th }}$ c. BC (2)

\begin{tabular}{|c|c|c|}
\hline (G) & $\mathrm{PES}_{2}$ & $\begin{array}{l}\text { 1. tarzi-, 'to turn; rout' } \\
\text { 2. pazza-, 'pass, walk' }\end{array}$ \\
\hline (H) & $\mathrm{PES}_{2} \cdot \mathrm{PES}$ & tarza-, 'oppose(?)' \\
\hline (I) & ASCIA & axe \\
\hline ( ) & *218 & $\begin{array}{l}\text { hahatta-, } \\
\text { 'to annihilate' }\end{array}$ \\
\hline (K) & *314 & has- 'to beget' \\
\hline
\end{tabular}

The double determinative $\mathrm{PES}_{2}$.PES for tarza-, (ARSUZ 1\& $2 \S 24 \mathrm{~b}$ ) contextually determines a verb of hostile meaning, 'oppose' aut sim..$^{35}$ In view of the iconic motivation of PES vs. $\mathrm{PES}_{2}$ discussed above, it is to be expected that on an iconic level, these two feet likewise represent a meaningful depiction for the semantic field of the host, i.e. denoting hostility, opposition. Note the closely similar usage of the determinative $\mathrm{PES}_{2}$ for tarzi-, 'to turn; rout', ${ }^{36}$ in the same inscription (ARSUZ $1 \S 13$ ). The simple determinative $\mathrm{PES}_{2}$ is already attested a little earlier with another verb, pazza-, 'to walk; pass' (SHEIZAR § 2). ${ }^{37}$

The verbal determinative ASCIA for karmali-, 'to hack', is only attested once (KARKAMIŠ A1a § 3) and may be an ad hoc creation, iconically enhancing the writing by depicting the tool used in the activity described. The determinative ${ }^{\star} 218$ for hahatta-, 'to annihilate', survives likewise in a single attestation (KARKAMIŠ A1a $\S 12)$, yet the icon used is less clear and later use as a determinative of other words does not help to elucidate it. Last but not least, the unexplained sign ${ }^{*} 314$ is introduced at this period as a determinative of has-, to beget'.

\section{Summary}

It has been shown that during the first four centuries of $\mathrm{AH}$ inscriptions, the increase in the number of determinative signs is slow and gradual, although the $10^{\text {th }}$ century $\mathrm{BC}$ already begins to show an acceleration which will reach its peak at the turn of the century. The earliest system is dominated by the taxonomic group 'names'. These show a semantic overlap with determinative signs used in Hittite cuneiform, and their creation may have been influenced by knowledge of such a group of determinatives. However, from the beginning the AH script favoured a frontal position of the determinative before the host, so that even in the small group of semantically similar determinatives, Hittite cuneiform and AH rarely share the same position for any one determinative. Should a knowledge of cuneiform determinatives have provided the spark for introducing them in $\mathrm{AH}$, the preferred pre-position may easily be explained with the iconic character of the script; placing a highly pictorial marker in front of its host may have felt natural as a case of 'show-and-tell', and it provided an additional benefit as a marker of the beginning of a word..$^{38}$

35 Cf. the discussion in Dinçol et al. (2015: 68).

36 On tarza/i-, cf. Rieken (2004).

37 On the metaphor 'walking through time' cf. Yakubovich (2016: 77-81); contra Melchert (2004: 375-377).

38 It is important to remember that the practice of marking the beginning of a word with the sign * 386 only began gradually, and even when the sign was widely used to mark the beginning of words, this was never to the detriment of using determinatives. 
Similarities with cuneiform predominantly lie in using determinatives of a comparable taxonomic group as structural writing elements but in one instance, with the personal marker, it is possible that the hieroglyphic scribes adopted the same principle of using a low saliency single vertical mark. Further, the unusual position of the two determinatives for city and region may have adopted an otherwise unusual position at the end of the word under the influence of a cuneiform parallel. While the position of determinatives in front of the host is a distinct feature of the AH system, possibly caused by the pictorial character of the script, a few determinative signs show other placement. In the case of postpositioned LITUUS ${ }^{39}$, it remains uncertain whether this attests to a level of experimentation or was caused by other considerations now obscured by the passage of time. Yet for the sign ${ }^{\star} 404^{40}$, a plausible case can be built for iconic logic overriding the inherent positional rules of the writing system.

The second stage of determination after the 'name' category already involves verbal determinatives, and can no longer be related to any possible cuneiform inspiration. A dominant principle is reinforcement of the host with the semantogram which also functions as the logogram for the host word, a principle which continues throughout the entire period in which the script was used. Secondarily, such one-to-one relationships between determinative and host could be extended to broaden the use of a determinative for a semantically linked (e.g. INFANS ${ }^{41}$; BONUS ${ }^{42}$ ) or linguistically linked (e.g. SOLIUM ${ }^{43}$ ) group of other words. It is frequently possible to define a central member of such a group as the starting point. Exchange of previously established icons for new ones (BONUS for BONUS $_{2}{ }^{44}$ ) attests reconsideration, and ensuing modification of the system.

Compounding individual signs to make up a new sign is not uncommon even with early determinative signs (e.g. INFANS, ${ }^{*} 428^{45}$ ), while compound determinatives that stay separate on a visual level will remain a relatively minor group amongst determinatives, although as a trend, they are more frequently attested in later periods. The spark for split compounds may have lain in the desire to show plurality or sufficiency through graphic reduplication (e.g. PANIS $_{2}$.PANIS ${ }^{46}$ ). Scribes extended this to representations of separate, complimentary notions, such as showing a tool-product relationship: e.g. a carved stone with the carving tool (LAPIS $\times$ SCALPRUM ${ }^{47}$ ). The opposition of visually separate and merged compounds raises the question whether and how the fusion or lack of it adhered to purely visual considerations, such as best used of available space, or possible aesthetic concerns, or whether it bore added meaning; no general answer is forthcoming but the question must be considered individually.

Importantly, determination can be shown to be an integral feature of the writing system from a relatively early point onwards, exploring the iconic potential of the script while at the same time operating not just on a level of reference to real world objects but also on a meta-level which made use of system-internal iconography.

Pictures: by Annick Payne.

Thanks: The research for this article was funded by eikones NCCR iconic criticsm, University of Basel. I would like to thank Craig Melchert, Ilya Yakubovich and Joost Hazenbos for comments on the draft version.

39 Table $5(\mathrm{~A})$.

40 Table 6 (G).

41 Table 5 (B).

42 Table 7 (A).

43 Table 5 (D).

44 Table 5 (C).

45 Table $5(\mathrm{~F})$.

46 Table 6 (B).

47 Table 7 (C). 


\section{Bibliography}

d'Alfonso, L. (2014): The Kingdom of Tarhuntassa: A Reassessment of its Timeline and Political Significance. In: P. Taracha/M. Kapeluś (ed.), Proceedings of the Eighth International Congress of Hittitology (Warsaw, 5-9 September 2011), Warsaw, 216-235.

Dinçol, B. et al. (2015): Two New Inscribed Storm-god Stelae from Arsuz (İskenderun): ARSUZ 1 and 2, AnSt. 65, 59-77.

Goldwasser, O./A. Payne (forthcoming): ANIMALIA in the Ancient Near East: Of Tail, Hide and Breath.

Goedegebuure, P. (2011/online): The Deeds (?) of Suppiluliuma II: The Südburg Inscription Reconsidered. Presentation September $5^{\text {th }}, 2011,8^{\text {th }} \mathrm{ICH}$, Warsaw, https://www.academia.edu/7487575/The_Deeds_of_Suppiluliuma_II_-_The_Südburg_ inscription_reconsidered (1.2.2017).

Hawkins, J.D. (1981): Kubaba at Karkamiš and Elsewhere, AnSt. 31, 147-176.

Hawkins, J.D. (1995): The Hieroglyphic Inscription of the Sacred Pool Complex at Hattusa (SÜDBURG). With an Archaeological Introduction by Peter Neve (StBoT Beih. 3), Wiesbaden.

Hawkins, J.D. (2000): Corpus of Hieroglyphic Luwian Inscriptions, 3 vol., Berlin - New York.

Hawkins, J.D. (2011): The Inscriptions of the Aleppo Temple, AnSt. 61, 35-54.

Hawkins, J.D./A. Morpurgo Davies (1978): On the Problems of Karatepe: The Hieroglyphic Text, AnSt. 28, 103-119.

Klinger, J. (2015): Šuppiluliuma II. und die Spätphase der hethitischen Archive. In: A. Müller-Karpe et al. (ed.), Saeculum. Gedenkschrift für Heinrich Otten anlässlich seines 100. Geburtstags (StBoT 58), Wiesbaden, 87-112.

Marrazzi, M. (2010): Scrittura, percezione e cultura: qualche riflessione sull’Anatolia in età hittita, Kaskal 7, 219-255.

Melchert, H.C. (1988): “Thorn” and “Minus” in Hieroglyphic Luvian Orthography”, AnSt. 38, 29-42.

Melchert, H.C. (2004): A Luwian Dedication. In: J.H.W. Penney (ed.), Indo-European Perspectives. Studies in Honour of Anna Morpurgo Davies, Oxford - New York, 370-379.

Melchert, H.C. (2010): History of the "Lituus" in the Anatolian Hieroglyphs (Handout of $220^{\text {th }}$ AOS Meeting, St. Louis).

Melchert, H.C. (forthcoming): Hittite and Luvian uppa- and Hittite uiya-. In: A. Süel (ed.), Proceedings of the Nineth International Congress of Hittitology.

Oreshko, R. (2017): Hartapu and the Land of Maša: A New Look at the KIZILDAĞ-KARADAĞ Group, AoF 44, 47-67.

Oreshko, R. (forthcoming): Studies in Hieroglyphic Luwian: Towards a Philological and Historical Reinterpretation of SÜDBURG Inscription (Dissertation FU Berlin 2012).

Payne, A. (2015): Schrift und Schriftlichkeit: Die anatolische Hieroglyphenschrift, Wiesbaden.

Payne, A. (in press ${ }^{1}$ ): Determination in the Anatolian Hieroglyphic Script, News from the Lands of the Hittites 1 (online journal, 2017).

Payne, A. (in press ${ }^{2}$ ): Compound Determinatives. In: J.C. Johnson et al. (ed.), Proceedings of "Die Sprache des Bewusstseins und das Bewusstsein von Sprache im Alten Orient”, Berlin 17/11/2014.

Poetto, M. (1993): L'iscrizione luvio-geroglifica di Yalburt: Nuove acquisizioni relative alla geografia dell'Anatolia sud-occidentale (StMed. 8), Pavia.

Rieken, E. (2004): Luwisch tarza/i-. In: A. Hyllested et al. (ed.), Per aspera ad asteriscos. Studia indogermanica in honorem Jens Elmegård Rasmussen sexagenarii Idibus Martiis anno MMIV (IBK 112), Innsbruck, 457-468.

Simon, Z. (forthcoming): The Hieroglyphic Luwian hapax “AVIS”(-)ta-wa/i-na-ri+i in SULTANHAN § 12. In: A. Süel (ed.), Proceedings of the Nineth International Congress of Hittitology.

Starke, F. (1990): Untersuchungen zur Stammbildung des keilschriftluwischen Nomens (StBoT 31), Wiesbaden.

van den Hout, Th. (2010): The Hieroglyphic Signs L. 255/256 and KARATEPE I. In: I. Singer (ed.), ipamati kistamati pari tumatimis. Luwian and Hittite Studies Presented to J. David Hawkins on the Occasion of His 70 $0^{\text {th }}$ Birthday, Tel Aviv, 234-243.

Yakubovich, I. (2005): Carian monument. In: N.N. Kazansky et al. (ed.), Hrōā manasā. Сборник статей к семидесятилетию со дня рождения Леонарда Георгиевича Герценберга, Saint-Petersburg, 240-251.

Yakubovich, I. (2008): The Luvian Enemy, Kadmos 47, 1-19.

Yakubovich, I. (2016): Some Transitive Motion Verbs and Related Lexemes in Late Luwian, IF 121, 69-92.

Yakubovich, I. (forthcoming): The Mighty Weapon of Tarhunt. 